Paulina Maria Nowicka*, Janusz Kocik**

\title{
Zewnętrzne zagrożenia bezpieczeństwa zdrowotnego Polski
}

\begin{abstract}
External threats to Poland's health security: Since the United Nations Security Council's declaration that a disease outbreak may be considered a threat to the stability and security of state, the widespread use of the term "health security" has begun. This paper presents the concept of health security along with its threats, with particular focus on the new phenomena related to globalisation which contribute to the occurrence of new health threats. The threats to Poland's health security are divided into internal and external. Internal ones may occur when the authorities do not meet the health needs of society. However, policymakers from industrialized countries put emphasis on protecting the population from external health security threats, especially from those that may become cross-border threats.
\end{abstract}

Słowa kluczowe: bezpieczeństwo zdrowotne Polski, bezpieczeństwo narodowe, zdrowie publiczne

Keywords: health security of Poland, national security, public health

* Lekarz w Zakładzie Profilaktyki Zagrożeń Środowiskowych i Alergologii Warszawskiego Uniwersytetu Medycznego, specjalista ds. międzynarodowych przepisów zdrowotnych w Krajowym Punkcie Centralnym ds. Międzynarodowych Przepisów Zdrowotnych, Narodowy Instytut Zdrowia Publicznego - Państwowy Zakład Higieny; e-mail: pnowicka@wum.edu.pl

** Doktor hab. nauk medycznych, kierownik Zakładu Gerontoonkologii Szkoły Zdrowia Publicznego Centrum Medycznego Kształcenia Podyplomowego w Warszawie; e-mail: janusz.kocik@cmkp.edu.pl.

\section{Wstęp}

O rozprzestrzeniającej się ponad granicami państw chorobie, której towarzyszyła wielka śmiertelność, wspominał już w V wieku p.n.e. Tukidydes ${ }^{1}$, ale pierwsze udokumentowane potraktowanie choroby jako zewnętrznego zagrożenia bezpieczeństwa państwa wraz z przyjęciem środka zaradczego w postaci kwa-

\footnotetext{
1 Tukidydes, Wojna peloponeska, Czytelnik, Warszawa 2003.
} 
rantanny miało miejsce w Republice Weneckiej w XIV wieku podczas epidemii dżumy. Z kolei wiek XVI naznaczony był epidemiami ospy, odry i grypy, które, wraz z działaniami roznoszących europejskie patogeny konkwistadorów, przyczyniły się do depopulacji Nowego Świata i upadku cywilizacji Azteków i Inków ${ }^{2}$. Kiedy w XIX wieku doszło do nawiązania wielu nowych relacji handlowych między Europą a resztą świata, wzrosło ryzyko przywlekania chorób zakaźnych z innych kontynentów. Choroby zostały uznane wówczas za zagrożenie zewnętrzne, a próbowano walczyć z nimi przy pomocy wprowadzenia regulacji zdrowotnych.

Osoby zajmujące się bezpieczeństwem wojskowym zaczęły zwracać uwagę na kwestie zdrowotne w kontekście użycia materiału biologicznego jako broni, epidemii osłabiających niestabilne państwa, zagrożeń zdrowia żołnierzy i humanitarnego wpływu działań wojskowych. Możliwość użycia materiału biologicznego w broni masowego rażenia przykuła uwagę społeczeństwa i spowodowała umieszczenie kwestii zdrowotnych w narodowych strategiach bezpieczeństwa ${ }^{3}$.

Według konstytucji Światowej Organizacji Zdrowia (WHO), uchwalonej 22 lipca 1946 r. w Nowym Jorku, zdrowie wszystkich ludów to podstawa dla osiągnięcia pokoju i bezpieczeństwa4. Jednak przez dziesiątki lat próby odnajdywania punktów stycznych dla dziedzin dotyczących zdrowia oraz badań nad bezpieczeństwem pozostawały bez echa. Wraz z coraz wyraźniej zarysowaną wizją nuklearnej konfrontacji światowa polityka zaczęła koncentrować się na uniknięciu kolejnej wojny. Jednocześnie XX wiek obfitował w postępy w dziedzinie medycyny, co przybliżało obraz świata, w którym uda się zapanować nad chorobami zakaźnymi. Umieralność z powodu chorób zakaźnych na Zachodzie spadała, a w 1980 r. po raz pierwszy w historii doszło do eradykacji choroby zakaźnej będącej przyczyną największej liczby przypadków śmiertelnych ze wszystkich chorób epidemicznych - ospy prawdziwej. Jednak pod koniec lat 90. optymistyczne przekonanie o pokonaniu chorób zakaźnych zaczęło wygasać. W wyniku analizy dokonanej w 1999 r. przez CIA określono zagrożenie, jakie globalny poziom chorób zakaźnych stanowił dla USA, uwzględniając nowe czynniki rozprzestrzeniania się chorób zakaźnych, jak wzrost międzynarodowego przepływu towarów i osób. Zwrócono również uwagę na kwestię zagrożeń, jakie choroby mogą stwarzać dla stabilności ładu międzynarodowego. Autorzy analizy doszli do wniosku, że problem chorób zakaźnych ściśle wiąże się z bez-

2 M.W. Solarz, Choroby a współczesna mapa polityczna świata [w:] Ochrona zdrowia w stosunkach międzynarodowych, red. W. Lizak, A.M. Solarz, Wydawnictwa Uniwersytetu Warszawskiego, Warszawa 2015, s. 41-60.

${ }^{3}$ Commission on Human Security, Human Security Now, Nowy Jork 2003, https:// reliefweb.int/sites/reliefweb.int/files/resources/91BAEEDBA50C6907C1256D19006A9353-chs-security-may03.pdf [dostęp: 10 lutego 2018 r.].

${ }^{4}$ Konstytucja Światowej Organizacji Zdrowia, http://prawo.sejm.gov.pl/isap.nsf/download.xsp/WDU19480610477/O/D19480477.pdf [dostęp: 10 lutego 2018 r.]. 
pieczeństwem narodowym ${ }^{5}$. Co więcej, Rada Bezpieczeństwa Organizacji Narodów Zjednoczonych w przyjętej 17 lipca 2000 r. rezolucji nr 1308, szczegółowo analizując możliwy wpływ HIV/AIDS na funkcjonowanie misji pokojowych, ostrzegała, że nieopanowana pandemia HIV/AIDS może stanowić zagrożenie dla stabilności i bezpieczeństwa ${ }^{6}$. Zagrożenie zdrowia stało się problemem polityki globalnej, urosło do rangi zagrożenia bezpieczeństwa międzynarodowego.

Celem autorów niniejszego artykułu jest przedstawienie pierwszych, pojawiających się na arenie międzynarodowej definicji bezpieczeństwa zdrowotnego, jego zagrożeń, zwłaszcza w perspektywie niekontrolowanego szerzenia się chorób, ukazanie miejsca, jakie bezpieczeństwo zdrowotne zajmuje w „Strategii Bezpieczeństwa Narodowego RP”, oraz wskazanie kierunków jego wzmacniania.

\section{Bezpieczeństwo zdrowotne}

Zderzenie dwóch światów: zdrowia i bezpieczeństwa, jakie miało miejsce u progu XXI wieku, zaowocowało pojawieniem się nowego pojęcia - bezpieczeństwa zdrowotnego (health security). W maju $2001 \mathrm{r}$. ukazało się ono w rezolucji Światowego Zgromadzenia Zdrowia zatytułowanej Global health security: epidemic alert and response. Ostrzeżenia zawarte w rezolucji dotyczyły zjawisk związanych z globalizacją, które mogą być postrzegane jako zagrożenie światowego bezpieczeństwa zdrowotnego. Podkreślono, że choroby zakaźne rozprzestrzeniają się niezależnie od granic państw. Wzmożone ruchy ludności, czy to w ramach turystyki, czy migracji lub jako skutek katastrof bądź konfliktów zbrojnych oraz zmiany środowiska, połączone $\mathrm{z}$ urbanizacją i deforestacją, utwierdzały w przekonaniu, że zdarzenia niepożądane dotyczące zdrowia publicznego występujące na terenie jednego państwa mogą stać się zagrożeniem o zasięgu międzynarodowym ${ }^{7}$. Ta rezolucja poparła dążenie do rewizji „Międzynarodowych przepisów zdrowotnych" (International Health Regulations, IHR) - był to pierwszy krok łączący światowe bezpieczeństwo zdrowotne ze stosowaniem IHR8.

${ }^{5}$ Central Intelligence Agency, National Intelligence Estimate NIE99-17D: The Global Infectious Disease Threat and Its Implications for the United States, 2000, https://www.dni.gov/ files/documents/infectiousdiseases_2000.pdf [dostęp: 17 lutego 2018 r.].

${ }^{6}$ Rada Bezpieczeństwa ONZ, Rezolucja nr 1308 w sprawie pandemii HIV/AIDS oraz międzynarodowych operacji pokojowych, 17 lipca 2000 r., http://www.unaids.org/sites/ default/files/sub_landing/files/20000717_un_scresolution_1308_en.pdf [dostęp: 17 lutego 2018 r.].

7 WHO, Global health security: epidemic alert and response, WHO, Geneva 2001, http:// apps.who.int/iris/bitstream/10665/78789/1/ea54r14.pdf [dostęp: 27 grudnia 2017 r.].

8 „Międzynarodowe przepisy zdrowotne”, które zostały przyjęte przez kraje członkowskie WHO w 1969 r., były ukierunkowane na przeciwdziałanie chorobom zakaźnym (dżumie, cholerze, żółtej gorączce, ospie prawdziwej) i wymagały rewizji, która nastąpiła w 2005 r. Nowe „Międzynarodowe przepisy zdrowotne” weszły w życie 15 czerwca 2007 r. Ustanowiły nowe ramy prawne rozpoznawania zagrożeń epidemiologicznych i szybkiego reagowania. 
„Międzynarodowe przepisy zdrowotne” opracowane w roku 2005 są prawnym instrumentem służącym ochronie przed rozprzestrzenianiem się wszelkich zagrożeń zdrowotnych w skali globu i ograniczenia ich skutków, mają przyczyniać się do osiągnięcia możliwie najwyższego stopnia bezpieczeństwa zdrowotnego?.

Bezpośrednią odpowiedzią na ataki terrorystyczne z 2001 r. w USA było stworzenie przez ministrów zdrowia ośmiu państw Inicjatywy na rzecz Światowego Bezpieczeństwa Zdrowotnego (Global Health Security Initiative, GHSI) ${ }^{10}$. Dążenia zaangażowanych w Inicjatywę określono następująco: poprawa bezpieczeństwa zdrowotnego na całym świecie, lepsze przygotowanie do odpowiedzi na akty biologicznego, chemicznego i radio-jądrowego terroryzmu ${ }^{11}$. W porównaniu z koncepcją przedstawioną przez Światowe Zgromadzenie Zdrowia pojęcie „bezpieczeństwo zdrowotne” w rozumieniu GHSI zostało znacznie zawężone. Po tragicznych wydarzeniach z 2001 r. stało się częścią międzynarodowych wysiłków zmierzających do przeorientowania strategii bezpieczeństwa wokół zagrożeń, jakie stwarzał terroryzm.

W tym czasie ideą bezpieczeństwa zdrowotnego zainteresowała się również Unia Europejska. Komisja Europejska, na wniosek ministrów zdrowia, utworzyła w 2001 r. Komitet ds. Bezpieczeństwa Zdrowia (Health Security Committee, HSC) jako nieformalną grupę doradczą ${ }^{12}$. W decyzji nr 1082/2013/UE wzmocniono jego rolę, formalizując podstawy, na jakich funkcjonował. Do zadań HSC należy: koordynowanie w porozumieniu z Komisją Europejską komunikacji w zakresie ryzyka i sytuacji kryzysowych oraz reagowania państw członkowskich na poważne zagrożenia zdrowia, koordynowanie działań państw członkowskich w zakresie planowania gotowości i reagowania oraz wspieranie wymiany informacji między państwami członkowskimi a Komisją na temat doświadczeń uzyskanych w zakresie wdrażania decyzji nr 1082/2013/UE ${ }^{13}$.

Światowa Organizacja Zdrowia w raporcie z 2007 r. pt. A Safer Future: Global Public Health Security in the 21st Century zdefiniowała bezpieczeństwo zdrowotne w następujący sposób: wymagane działania, zarówno o charakterze reak-

Szerzej zob. A. Kicman-Gawłowska, Nadzór nad chorobami zakaźnymi w świetle Międzynarodowych Przepisów Zdrowotnych (2005), „Przegląd Epidemiologiczny” 2008, t. 62, s. 739-749.

9 A. Wojtczak, Zdrowie publiczne wyzwaniem dla systemów zdrowia XXI wieku, Wydawnictwo Lekarskie PZWL, Warszawa 2009, rozdz. Globalizacja a zdrowie publiczne, s. 179-191.

${ }^{10}$ S. Elbe, Health Security: The Medicalization of Security in the Twenty-First Century [w:] S. Elbe, Security and global health, Polity Press, Cambridge 2010, s. 1-29.

${ }_{11}$ Global Health Security Initiative, Ministerial Statement, 2002, http://www.ghsi.ca/ english/statementlondonmar2002.asp [dostęp: 17 lutego 2018 r.].

12 Główny Inspektorat Sanitarny, Wspólpraca międzynarodowa, https://gis.gov.pl/en/ zdrowie/transgraniczne-zagrozenia-zdrowia-publicznego/wspolpraca-miedzynarodowa [dostęp: 18 lutego 2018 r.].

${ }_{13}$ Decyzja Parlamentu Europejskiego i Rady nr 1082/2013/UE z 22 października 2013 r. w sprawie poważnych transgranicznych zagrożeń zdrowia, Dz.Urz.UE L 293 z 5 listopada $2013 \mathrm{r}$ 
tywnym i proaktywnym, służace zredukowaniu podatności na ostre zagrożenia dotyczace zdrowia publicznego, które zagrażaja zbiorowemu zdrowiu ludności zamieszkującej różne regiony geograficzne ${ }^{14}$. Użyte pojęcie „ostre zagrożenia dotyczące zdrowia publicznego" okazało się wystarczająco pojemne, by zmieścić zarówno zagrożenia bioterrorystyczne, jak i naturalnie wybuchające epidemie.

Bezpieczeństwo zdrowotne jako pojęcie ewoluuje, dlatego nie istnieje jedna definicja, która krótko i jasno wyjaśniłaby jego znaczenie. Bezpieczeństwo zdrowotne obejmuje między innymi zagadnienia związane z zapobieganiem powstawaniu zagrożeń zdrowia i z odpowiedzią na pojawiające się ogniska chorób i epidemie, ze zdrowiem jako instrumentem polityki oraz z przeciwdziałaniem zagrożeniom bioterroryzmem.

W raporcie o rozwoju społecznym z roku 1990 i przy okazji stworzenia wskaźnika rozwoju społecznego (Human Development Index, HDI) pojawiła się wzmianka o tym, że zdrowie zawiera się w bezpieczeństwie jednostki (human security). Podkreślono rolę życia w dobrym zdrowiu oraz edukacji w procesie rozwoju ludzkości. Również przyjęte dekadę później „Milenijne cele rozwoju" nawiązywały w sposób mniej lub bardziej bezpośredni do poprawy stanu zdrowia ludzi w rozwijającym się świecie ${ }^{15}$. Na human security, według raportu o rozwoju społecznym z roku 1994, składa się siedem elementów: bezpieczeństwo ekonomiczne, żywnościowe, zdrowotne, środowiskowe, osobiste, społeczne i polityczne. W raporcie znajduje się również teza, że przewlekłe zagrożenia, takie jak głód czy choroby, mogą osłabiać human security w podobnym stopniu jak wojna czy konflikt wewnętrzny ${ }^{16}$. Bezpieczeństwo zdrowotne uznano za rdzeń human security, a choroby, niepełnosprawność i śmierć, których można było uniknąć - za szerzące się, krytyczne zagrożenia dla bezpieczeństwa jednostki. Zdrowie rozumiane jest tutaj nie tylko jako brak choroby, lecz jako stan całkowitego, fizycznego, psychicznego i społecznego dobrostanu. Z tego punktu widzenia życie w dobrym zdrowiu ma zasadnicze znaczenie dla ludzkiej godności oraz dla human security.

Obecnie często zdarza się, że to osoba, która używa terminu „,bezpieczeństwo zdrowotne" decyduje o jego znaczeniu. Wynika to z faktu, że jest to zagadnienie, nad którym prace prowadzą zarówno eksperci studiów nad bezpieczeństwem, stosunków międzynarodowych, jak i lekarze czy pracownicy agencji Organizacji

${ }^{14}$ Oryg.: the activities required, both proactive and reactive, to minimalize vulnerability to acute public health events that endanger the collective health of populations living across geographical regions, WHO, A Safer Future: Global Public Health Security in the 21st Century, The World Health Report 2007, Geneva, tłum. własne, http://www.who.int/entity/whr/2007/ whr07_en.pdf?ua=1 [dostęp: 18 lutego 2018 r.].

15 ONZ, Millennium Development Goals, http://www.un.org/millenniumgoals/ [dostęp: 5 listopada 2018 r.].

16 Program Narodów Zjednoczonych ds. Rozwoju, Human Development Report, 1994, http://hdr.undp.org/sites/default/files/gomez_hdr14.pdf [dostęp: 5 listopada 2018 r.]. 
Narodów Zjednoczonych. Nawet w samej ONZ występują rozbieżności co do definicji bezpieczeństwa zdrowotnego, np. między Programem Narodów Zjednoczonych ds. Rozwoju a Światową Organizacją Zdrowia. Organizacja Narodów Zjednoczonych przyjmuje szerszą perspektywę, uważając, że zagrożenia bioterroryzmem czy pandemiami stanowią zagrożenia zdrowotne głównie w ocenie państw Zachodu. Sugeruje, by bezpieczeństwo zdrowotne obejmowało choroby endemiczne krajów tzw. Globalnego Południa, z którymi nierzadko nie radzą sobie systemy opieki zdrowotnej niskiej jakości ${ }^{17}$.

Niezależnie od przyjętej definicji, związek między zdrowiem a bezpieczeństwem istnieje, został zauważony $i$ jest wart dalszych badań $i$ analiz.

\section{Kategorie zagrożeń bezpieczeństwa zdrowotnego}

Zagrożenia bezpieczeństwa zdrowotnego można podzielić ze względu na ich źródło na zewnętrzne i wewnętrzne. Wewnętrzne wynikają z braku skutecznego, zorganizowanego wysiłku społecznego, realizowanego głównie przez wspólne działania instytucji publicznych, mającego na celu polepszenie, promocję, ochronę i przywracanie zdrowia ludności ${ }^{18}$. Są łatwiejsze do zaobserwowania i przewidzenia od zewnętrznych. Decydenci z państw uprzemysłowionych kładą nacisk na ochronę ludności przed zewnętrznymi zagrożeniami bezpieczeństwa zdrowotnego, zwłaszcza przed terroryzmem i pandemiami ${ }^{19}$. Przykładem aktu terrorystycznego, który oprócz konsekwencji zdrowotnych generował olbrzymie straty ekonomiczne, było rozesłanie w czterech listach spor bakterii wąglika w USA w 2001 r. Spowodowało to zakażenie 22 osób i paraliż systemu pocztowego ${ }^{20}$. Odpowiednie leki zostały rozdystrybuowane do 33 tys. pracowników, którzy mogli być narażeni na kontakt z patogenem ${ }^{21}$. Dodatkowo wydano 1,7 mld dolarów US na zainstalowanie specjalnego systemu filtrów i wykrywania zagrożeńn ${ }^{22}$.

Zagrożenia zewnętrzne mogą być pochodzenia biologicznego, chemicznego, środowiskowego lub nieznanego (wykres 1).

17 S. Elbe, Health Security, op. cit., s. 1-29.

18 WHO, Health Systems Strengthening Glossary, http://www.who.int/healthsystems/ hss_glossary/en/index8.html [dostęp: 4 listopada 2018 r.].

19 W. Aldis, Health security as a public health concept: a critical analysis, „Health Policy and Planning" 2008, t. 23, nr 6, s. 369-375.

${ }^{20}$ Federal Bureau of Investigation, Amerithrax or Anthrax Investigation, https://www.fbi. gov/history/famous-cases/amerithrax-or-anthrax-investigation [dostęp: 19 czerwca $2018 \mathrm{r}$.]

${ }^{21}$ Heyman D., Lessons from the Anthrax Attacks: Implications for U.S. Bioterrorism Preparednes. A Report on a National Forum on Biodefense, kwiecień 2002 r., https://biotech.law. lsu.edu/blaw/anthrax/dtra02.pdf [dostęp: 19 czerwca 2018 r.].

22 A. Wojtczak, Zdrowie publiczne, op. cit., s. 179-191. 


\section{Wykres 1. Podział zagrożeń bezpieczeństwa zdrowotnego ze względu na pochodzenie}

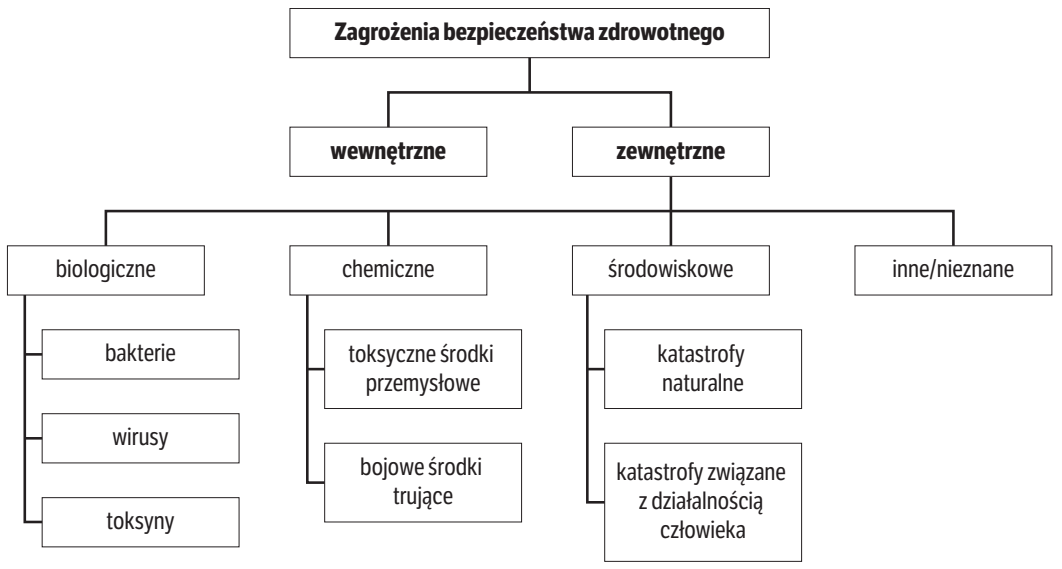

Czynnikiem sprzyjającym rozprzestrzenianiu się zagrożeń pochodzenia biologicznego jest zwiększona mobilność osób, zwierząt i mikroorganizmów ${ }^{23}$. Dla patogenów, które kiedyś potrzebowały miesięcy czy lat, aby wyjść poza granice regionu, z którego pochodzą, obecnie okrążenie globu to kwestia godzin.

Według Światowej Organizacji Turystyki ruch turystyczny w 2017 r. wzrósł w stosunku do 2016 r. o 7\% ${ }^{24}$. Międzynarodowe połączenia lotnicze zwiększyły prędkość i zakres ludzkiej mobilności, a przy okazji doprowadziły do stworzenia światowej sieci transportowej dla chorób zakaźnych. Patogeny mogą trafić na obszary, na których ich dotychczas nie spotykano, a rozprzestrzenianie się nowych czy zmutowanych czynników zoonotycznych jest ułatwione $e^{25}$.

Zakażenie drobiu wirusem H5N1 w 2003 r., które objęło kilkadziesiąt krajów Azji, Europy i Afryki, spowodowało wybicie $100 \mathrm{mln}$ sztuk drobiu, 310 przypadków zakażeń tym wirusem u ludzi i 189 zgonów ${ }^{26}$. Innym przykładem zewnętrznego zagrożenia bezpieczeństwa zdrowotnego o pochodzeniu biologicznym była epidemia gorączki krwotocznej Ebola. Ogłoszona stanem zagrożenia zdrowia publicznego o zasięgu międzynarodowym była najpoważniejszą epidemią tej choroby w historii. Wystąpiła jednocześnie w trzech krajach (Gwinei, Liberii i Sierra Leone) u 28 tys. osób, a 11 tys. doprowadziła do zgonu, w tym u setek pracowników opieki zdrowotnej. Przekształciła się w kryzys hu-

23 A. Wojtczak, Zdrowie publiczne, op. cit., s. 41-58.

24 Światowa Organizacja Turystyki, http://www2.unwto.org/press-release/2018-08-27/ unwto-highlights-confirm-another-record-year-2017 [dostęp: 27 sierpnia 2018 r.].

25 G. Martin, M. Boland, Planning and preparing for public health threats at airports, „Globalization and Health” 2018, t. 14, nr 28, https://doi.org/10.1186/s12992-018-0323-3.

26 A. Wojtczak, Zdrowie publiczne, op. cit., s. 179-191. 
manitarny i społeczno-gospodarczy ${ }^{27}$. Dodatkowym czynnikiem utrudniającym walkę z nieznającymi granic mikrobami jest wykształcenie przez część z nich mechanizmu obronnego - oporności na antybiotyki (uznanej przez WHO za zagrożenie bezpieczeństwa zdrowotnego w $2014 \mathrm{r}^{28}{ }^{28}$. W erze postantybiotykowej zwykłe infekcje lub drobne zranienia mogą okazać się śmiertelne.

Osoby planujące podróż powinny szukać informacji na temat potencjalnych zagrożeń zdrowotnych w miejscach będących celem podróży, aby chronić swoje zdrowie. Zasięgnięcie porady lekarskiej przed planowaną podróżą pozwala na ustalenie potrzeby wykonania szczepień lub rozpoczęcia chemioprofilaktyki malarycznej ${ }^{29}$.

Należącym do kolejnej grupy zagrożeń bezpieczeństwa zdrowotnego - zagrożeń chemicznych, jest przykład powtarzającego się łamania konwencji o zakazie broni chemicznej podczas konfliktu w Syrii poprzez użycie jako środka bojowego trującego gazu - sarinu ${ }^{30}$, w tym w 2013 r. w Ghucie.

Zagrożeniem zarówno o charakterze chemicznym, jak i środowiskowym była katastrofa spowodowana działaniem ludzkim - w 2006 r. wokół Abidżanu (Wybrzeże Kości Słoniowej) wyrzucono około 500 ton odpadów petrochemicznych, co spowodowało zatrucie 90 tys. osób i ryzyko zanieczyszczenia rzeki przepływającej przez kilka państw. Katastrofą o podobnym pochodzeniu był wyciek odpadów w hucie aluminium na Węgrzech w październiku 2010 r. Fala żrącego, czerwonego szlamu dotarła najpierw do pobliskich miejscowości, powodując ofiary śmiertelne i obrażenia ciała, a następnie do Dunaju, mobilizując państwa leżące w dole rzeki do opracowania planów działania.

Zagrożeniami o pochodzeniu stricte środowiskowym są: trzęsienie ziemi, erupcja wulkanu, tsunami, cyklony czy tornada. Ekstremalne temperatury również należą do tej kategorii ${ }^{31}$. Tylko w $2016 \mathrm{r}$. z powodu katastrof naturalnych ucierpiało 569,4 mln osób (najwięcej od 2006 r.) ${ }^{32}$.

27 Europejski Trybunał Obrachunkowy, Special Report: Dealing with serious cross-border threats to health in the EU: important steps taken but more needs to be done, Urząd Publikacji Unii Europejskiej, Luksemburg 2016, https://www.eca.europa.eu/Lists/ECADocuments/ SR16_28/SR_HEALTH_EN.pdf [dostęp: 17 lutego 2018 r.].

${ }_{28}$ WHO, Antimicrobial resistance: global report on surveillance 2014, http://www.who. int/iris/bitstream/10665/112642/1/9789241564748_eng.pdf?ua=1 [dostęp: 17 lutego 2018 r.].

${ }_{29}$ WHO, International travel and health, http://www.who.int/ith/ITH_EN_2012_ WEB_1.2.pdf?ua=1 [dostęp: 30 sierpnia 2018 r.].

30 Timeline of Syrian Chemical Weapon Activity 2012-2018, https://www.armscontrol. org/factsheets/Timeline-of-Syrian-Chemical-Weapons-Activity [dostęp: 18 lutego 2018 r.].

${ }^{31}$ Największe fale upałów nad zachodnią Europą w 2003 r. oraz Rosją w 2010 r. spowodowały śmierć 50 tys. osób, Centre for Research on the Epidemiology of Disasters, International Disaster Database, www.emdat.be [dostęp: 18 lutego 2018 r.].

32 Centre for Research on the Epidemiology of Disasters, Annual Disaster Statistical Review 2016, http://emdat.be/sites/default/files/adsr_2016.pdf [dostęp: 18 lutego 2018 r.]. 
Zewnętrzne zagrożenia bezpieczeństwa zdrowotnego mogą również wynikać z procesów globalizacji. Zintensyfikowane tempo urbanizacji i uprzemysłowienia, nasilony proces wycinania lasów zwiększają ryzyko wystąpienia powodzi czy huraganów, co powoduje wzrost podatności na zagrożenia środowiskowe, chemiczne i biologiczne.

Z kolei wewnętrzne zagrożenia bezpieczeństwa zdrowotnego wynikają między innymi z braku zapewnienia przez państwo opieki medycznej wysokiej jakości, tj. z niezaspokojenia potrzeb społeczeństwa w zakresie profilaktyki, promocji zdrowia, diagnostyki, leczenia i rehabilitacji ${ }^{33}$. Zwraca na to uwagę fakt, że wśród najczęstszych przyczyn śmierci w krajach rozwijających znajdują się powikłania okołoporodowe matek oraz zakażenia układu oddechowego i przewodu pokarmowego u dzieci. Często z zewnętrznych zagrożeń bezpieczeństwa zdrowotnego wynikają zagrożenia wewnętrzne, zauważalna jest zależność bezpieczeństwa zdrowotnego od suwerenności państwa i możliwości udzielania świadczeń zdrowotnych na jego terenie.

Zagrożenia bezpieczeństwa zdrowotnego widziane z perspektywy Światowej Organizacji Zdrowia można z kolei podzielić na trzy dość pojemne kategorie:

- choroby zakaźne,

- zagrożenia bezpieczeństwa żywności,

- katastrofy wpływające na środowisko.

Pierwsza kategoria, wbrew pozorom, nie mieści w sobie wszystkich chorób zakaźnych, lecz tylko nowe choroby lub nowe odmiany znanych chorób, które mogą stanowić nieznane wcześniej czynniki ryzyka. Druga - dotyczy zagrożeń płynących głównie z uprzemysłowienia rolnictwa. Trzecia kategoria zawiera zarówno katastrofy naturalne, jak i spowodowane działalnością człowieka (zamierzoną i przypadkową). Mieszczą się tu wypadki przemysłowe [wycieki toksyn, nieodpowiednie składowanie chemikaliów, incydenty jądrowe (Czernobyl, 1986 i Fukushima, 2011)], uwolnienie patogenów przez naruszenie protokołów bezpieczeństwa laboratoryjnego lub ich celowe wykorzystanie przez terrorystów oraz katastrofy naturalne. Zwraca uwagę poszerzenie koncepcji bezpieczeństwa zdrowotnego o kwestie dotyczące bezpieczeństwa żywności. Z perspektywy WHO światowe bezpieczeństwo zdrowotne jest wezwaniem do działania ${ }^{34}$.

Należy poświęcić osobną uwagę aktualnym zjawiskom socjodemograficznym, społecznym i środowiskowym, które mogą być katalizatorem pogorszenia bezpieczeństwa zdrowia publicznego w najbliższej przyszłości. Postępująca globalizacja jest wymieniana jako jeden z najsilniejszych czynników wpływu

${ }^{33}$ Ministerstwo Zdrowia, Jakość w opiece medycznej, http://www.mz.gov.pl/system-ochrony-zdrowia/organizacja-ochrony-zdrowia/jakosc-w-opiece-zdrowotnej/ [dostęp: 16 lutego $2018 \mathrm{r}$.].

${ }^{34}$ C. McInnes, The many meanings of health security [w:] Routledge Handbook of Global Health Security, red. S. Rushton, J. Youde, Routledge, Nowy Jork 2015, s. 7-17. 
(drivers) na poziom bezpieczeństwa zdrowotnego ${ }^{35}$. Masowy handel transgraniczny powoduje transmisję nowo wyłaniających się chorób zakaźnych. Jest to szczególnie widoczne w przypadku chorób szerzących się wśród zwierząt hodowlanych. Jak obserwowaliśmy w związku z grypą zwierząt (świń i ptactwa) oraz niektórymi nowo wyłaniającymi się chorobami wirusowymi (wirus Nipah, SARS) możliwe jest przeniesienie chorób odzwierzęcych na ludzi w rejonach o niskim statusie socjoekonomicznym i złym stanie sanitarno-higienicznym. Światowy handel i migracja powodują szybkie przejście chorób endemicznych do wymiaru pandemicznego.

Zmiany klimatu zwiększają zagrożenie rozszerzenia strefy tropikalnych chorób wektorowych do strefy klimatycznej naszego kraju. Dobrym dowodem na słuszność tej hipotezy jest pojawienie się przypadków choroby chikungunya, przenoszonej przez komary strefy tropikalnej do kontynentalnej części Włoch. Było to możliwe przez zawleczenie w trakcie kontaktów handlowych komara Aedes albopictus oraz coraz bardziej sprzyjające warunki pogodowe. Dla bezpieczeństwa zdrowia Polski ważne jest ryzyko dalszego szerzenia się chorób odkleszczowych, boreliozy i kleszczowego zapalenia mózgu. Wzrasta ono w przypadku ciepłych zim i wysokich temperatur w lecie, niskiej amplitudy zmian temperatury między porami roku i dłuższej wegetacji roślinności.

Masowa migracja do Europy ludności z regionów objętych konfliktami zbrojnymi na Bliskim Wschodzie, Ukrainie i Kaukazie oraz imigracja ekonomiczna do Polski wymagają dodatkowej uwagi z punktu widzenia bezpieczeństwa zdrowotnego. Utrzymuje się, że migranci nie stwarzają dodatkowego zagrożenia dla populacji kraju goszczącego ${ }^{36}$. Są oni jednak sami bardziej podatni na zachorowania na choroby zakaźne ${ }^{37}$. W krajach o niskiej zapadalności na choroby związane ze statusem socjoekonomicznym (np. na gruźlicę) większość nowych przypadków zachorowań odnotowuje się u imigrantów ${ }^{38}$.

Administracja publiczna w Polsce jest programowo przygotowana do sprostania wielosektorowym zadaniom $\mathrm{w}$ przypadku zagrożeń epidemicznych. Rządowe Centrum Bezpieczeństwa (RCB) we wspólpracy z ministerstwami, urzędami centralnymi i województwami, na podstawie ustawy o zarządzaniu

${ }^{35}$ J.C. Semenza, H. Zeller, Integrated surveillance for prevention and control of emerging vector-borne diseases in Europe, „Eurosurveillance” 2014, t. 19, nr 13, s. 207-257, https://doi. org/10.2807/1560-7917.ES2014.19.13.20757.

${ }^{36}$ J.C. Semenza i in., Observed and projected drivers of emerging infectious diseases in Europe, „Annals of the New York Academy of Sciences” 2016, t. 1382, nr 1, s. 73-83, https:// doi.org/10.1111/nyas.13132.

${ }^{37}$ J. Kocik, M. Jędras, Nowe wyzwania związane z migracją ludności, Bel Studio, Warszawa 2017.

${ }^{38} \mathrm{~K}$. Lonnroth i in., Tuberculosis in migrant in low-incidence countries: epidemiology and intervention entry points, „The International Journal of Tuberculosis and Lung Disease” 2017, t. 21, nr 6, s. 624-637, https://doi.org/10.5588/ijtld.16.0845. 
kryzysowym ${ }^{39}$ opracowuje systematycznie aktualizowany „Krajowy plan zarządzania kryzysowego” ${ }^{40}$. W jego ostatniej edycji wyszczególniono katalog przedsięwzięć, jakie powinny być realizowane w celu zminimalizowania ryzyka wystąpienia zagrożeń i/lub ograniczenia ich skutków. Wśród zagrożeń wymieniono między innymi powódź, epidemię, skażenie chemiczne, skażenie radiacyjne.

W fazie zapobiegania epidemii podmiotem wiodącym jest minister właściwy ds. zdrowia, zaś do podmiotów współpracujących zalicza się ministra właściwego ds. wewnętrznych, ministra ds. obrony narodowej, ministra właściwego ds. środowiska, ministra właściwego ds. rolnictwa, ministra właściwego ds. energii, Radę Ministrów, Rządowe Centrum Bezpieczeństwa i wojewodów. Zadania i obowiązki uczestników zarządzania kryzysowego przedstawiono $\mathrm{w}$ formie siatki bezpieczeństwa. Z kolei podmiotem odpowiedzialnym za monitorowanie zagrożeń epidemicznych jest Główny Inspektor Sanitarny wraz z Dyrektorem Narodowego Instytutu Zdrowia Publicznego - Państwowego Zakładu Higieny.

\section{Bezpieczeństwo zdrowotne w „Strategii bezpieczeństwa narodowego RP"}

W „Strategii bezpieczeństwa narodowego RP” pojęcie „bezpieczeństwo zdrowotne” pojawiło się dopiero w 2014 r. w następującej postaci: Bezpieczeństwo zdrowotne obywateli współkształtuje bezpieczeństwo narodowe. Wpływaja na nie nasilające się zmiany demograficzne, zmiany warunków środowiskowych oraz rozwój nowych technologiiti .

Dwa zdania poświęcone bezpieczeństwu zdrowotnemu w dokumencie liczącym 57 stron pozostawiają pewien niedosyt. Zwłaszcza biorąc pod uwagę szerzącą się już od roku przed przyjęciem najnowszej strategii epidemię wywołaną wirusem Ebola, uznaną przez WHO za zdarzenie nadzwyczajne, stanowiące zagrożenie dla innych państw ${ }^{42}$. Jeśli Afryka Zachodnia wydawała się odległa z punktu widzenia osób odpowiedzialnych za tworzenie strategii bezpieczeństwa Polski, to potwierdzone laboratoryjnie przypadki chorób zawleczone między innymi do Hiszpanii, Wielkiej Brytanii (2014) czy Włoch (2015)

39 Ustawa z 26 kwietnia 2007 r. o zarządzaniu kryzysowym, Dz.U. nr 89 poz. 590.

40 RCB, Krajowy Plan Zarządzania Kryzysowego, https://rcb.gov.pl/krajowy-plan-zarzadzania-kryzysowego/ [dostęp: 6 listopada 2018 r.].

41 Art. 53 „Strategii bezpieczeństwa narodowego RP”, 2014.

42 Zgodnie z kryteriami i procedurą określoną w przyjętych przez Polskę „Międzynarodowych przepisach zdrowotnych” z 2005 r., które są prawnym instrumentem służącym ochronie przed rozprzestrzenianiem się wszelkich zagrożeń zdrowotnych w skali globu i ograniczenia ich skutków, a przez to przyczyniają się do osiągnięcia możliwie najwyższego stopnia bezpieczeństwa zdrowotnego. Center for Disease Control and Prevention, Ebola, https://www.cdc.gov/niosh/topics/ebola/ [dostęp: 12 maja 2018 r.]. 
powinny zwrócić uwagę na bliskość zagrożenia ${ }^{43}$. Nacisk położony na zmiany demograficzne, środowiskowe i rozwój technologii jako na czynniki wpływające na bezpieczeństwo zdrowotne jest zastanawiający. Czy drastycznie spadającą wyszczepialność przeciwko chorobom zakaźnym na terenie Ukrainy ${ }^{44}$, związaną między innymi z toczącym się od 2014 r. konfliktem w Donbasie, można uznać za „zmianę warunków środowiskowych”?

Granica północno-wschodnia Polski jest równocześnie zewnętrzną granicą Unii Europejskiej i w związku z tym, jak zauważa Główny Inspektorat Sanitarny, na Polskę zostało nałożone szczególnie odpowiedzialne zadanie zagwarantowania bezpieczeństwa wszystkim państwom członkowskim i ochrony przed zagrożeniami zdrowotnymi, przy jednoczesnym utrzymywaniu dobrosąsiedzkich kontaktów z państwami pozostającymi poza Unią Europejską. Tymczasem „Strategia bezpieczeństwa narodowego RP” z 2014 r. zupełnie pomija zagrożenia bezpieczeństwa zdrowotnego pochodzenia biologicznego, których rozprzestrzenianiu sprzyja zwiększona mobilność osób, zwierząt i mikroorganizmów.

Liczba zachorowań na odrę na terenie Ukrainy, jakie miały miejsce od stycznia do sierpnia 2018 r., przekroczyła liczbę zachorowań na tę chorobę, do których doszło łącznie na terenie państw członkowskich Unii Europejskiej oraz obu Ameryk w tymże roku ${ }^{45}$. Najwięcej przypadków odnotowano w zachodnich regionach Ukrainy ${ }^{46}$. W czerwcu 2018 r. ukraińskie Ministerstwo Zdrowia oceniło stan zaszczepienia przeciwko odrze na ok. $50 \%^{47}$, co łącznie z wysoką liczbą zachorowań przyczyniło się do rozpoczęcia programu bezpłatnych szczepień dla osób dorosłych z grup ryzyka ${ }^{48}$.

Trwający od 2014 r. konflikt na terenie obwodu ługańskiego i donieckiego przyczynił się do wystąpienia wielu zagrożeń bezpieczeństwa zdrowotnego.

43 D.L. Heymann, A. West, Emerging infections. Threats to health and economic security [w:] Routledge Handbook of Global Health Security, red. S. Rushton, J. Youde, Routledge, New York 2018, s. 92-104.

44 W 2016 r. tylko 19\% dzieci na Ukrainie otrzymało trzecią dawkę szczepienia przeciwko błonicy, tężcowi i krztuścowi. Od 2008 do 2016 r. liczba zaszczepionych przeciwko odrze, śwince i różyczce dzieci spadła o 64\%. Dane pochodzą ze strony WHO.

45 D.W. Hackett, Measles Epidemic in Ukraine Exceeds 28,000 Cases, 19 sierpnia 2018 r., https://www.precisionvaccinations.com/level-1-international-travel-alert-issued-cdc-measles-epidemic-ukraine [dostęp: 20 sierpnia 2018 r.].

46 WHO, WHO situation report: Ukraine. April-June 2018, http://www.euro.who. int/_data/assets/pdf_file/0006/377484/who-sitrep-april-june-2018-eng.pdf?ua=1 [dostęp: 20 sierpnia 2018 r.].

47 Szczepienia.Info, Coraz więcej zachorowań na odrę i drugi przypadek błonicy na Ukrainie, 27 czerwca 2018 r., http://szczepienia.pzh.gov.pl/coraz-wiecej-zachorowan-na-odre-i-drugi-przypadek-blonicy-na-ukrainie/ [dostęp: 20 sierpnia 2018 r.].

48 R. Herriman, Ukraine measles cases continue to climb, 2nd diphteria case reported, 21 czerwca 2018 r., http://outbreaknewstoday.com/ukraine-measles-cases-continue-climb-2nd-diphtheria-case-reported-90867/ [dostęp: 20 sierpnia 2018 r. ]. 
Ataki na szpitale, zastraszanie personelu medycznego, utrudnianie dostępu organizacjom świadczącym pomoc humanitarną ograniczyły dostęp do świadczeń medycznych chorym i poszkodowanym. W ich wyniku może dojść do upośledzenia systemów odpowiedzialnych za kontrolę zakażeń, uniemożliwienia prowadzenia przewlekłych terapii czy zaprzepaszczenia dotychczasowych osiągnięć w profilaktyce chorób.

Włączenie zagadnienia bezpieczeństwa zdrowotnego do „Strategii bezpieczeństwa narodowego RP” z 2014 r. świadczy o dostosowywaniu treści tego dokumentu do zmieniających się uwarunkowań bezpieczeństwa. Aby jednak podążyły za nimi odpowiednie działania, niezbędne jest zrozumienie używanych pojęć, zwłaszcza przez aktualizację posiadanej wiedzy oraz śledzenie dynamicznej sytuacji dotyczącej nowo pojawiających się zagrożeń bezpieczeństwa zdrowotnego. Pobieżne potraktowanie zagadnienia wskazuje na brak poprzedzającej, wielosektorowej debaty, w której, oprócz ekspertów studiów nad bezpieczeństwem czy stosunków międzynarodowych, mogliby wziąć udział lekarze specjaliści epidemiologii i zdrowia publicznego czy przedstawiciele granicznych stacji sanitarno-epidemiologicznych.

Merytoryczna debata pozwoliłaby na spojrzenie na zagrożenia bezpieczeństwa zdrowotnego z punktu widzenia wielu dyscyplin oraz na wypracowanie ram teoretycznych dla tego zagadnienia w nowej strategii bezpieczeństwa państwa.

\section{Kierunki wzmacniania bezpieczeństwa zdrowia publicznego wobec zmieniających się zagrożeń epidemiologicznych i nowych technologii}

Systematyczna, bieżąca ocena zagrożeń dla zdrowia populacji, oparta na zbieraniu, interpretacji, analizie i udostępnianiu informacji na temat obecnie występujących zachorowań, umożliwia decydentom bardziej efektywne zarządzanie kryzysowe w przypadku zagrażających lub rozwijających się epidemii chorób zakaźnych. Możliwości analizy Big Data, tzn. masowych danych cyfrowych dostępnych w internecie, zmieniają podejście do nadzoru chorób zakaźnych i wywiadu epidemiologicznego, nacelowanych na analizę ryzyka i detekcję ognisk epidemicznych.

Wywiad epidemiologiczny oparty jest na wykrywaniu wskaźników i zdarzeń. Głównym celem nadzoru opartego na wskaźnikach statystycznych jest zidentyfikowanie zmian w zapadalności, czy to w formie nagłej zmiany, czy długofalowych zmian trendów. Opiera się on na formalnym systemie zbierania danych medycznych według określonych definicji przypadków chorobowych dostarczanych przez podmioty lecznicze, inspekcję sanitarno-epidemiologiczną, przy jej biernym lub aktywnym współudziale. Celem analizy danych jest wykrycie zwyżki liczbowej przypadków zachorowań w stosunku do trendów sezonowych lub zgrupowania zachorowań w czasie i przestrzeni. Komputerowe 
systemy informacji geograficznej ułatwiają obrazowanie sytuacji epidemiologicznej. Nawet w krajach o wysokim standardzie zdrowia publicznego nadzór konwencjonalny charakteryzuje się istotnym opóźnieniem, które upośledza wczesne reagowanie na rozpoczynającą się epidemię.

Celem przyspieszenia momentu rozpoznania epidemii naturalnych lub spowodowanych przez czlowieka w aktach bioterroru, w latach 90 . XX wieku rozwinięto wiele systemów nadzoru opartych na wczesnych objawach chorobowych. Automatyzacja analizy polega na łączeniu istotnych oznak i objawów zgłaszanych przez pacjentów w pierwszym kontakcie $\mathrm{z}$ opieką zdrowotną w zespoły chorobowe, zgodne z definicją przypadku najgroźniejszych chorób zakaźnych. W dobrze zorganizowanych służbach epidemiologicznych wojsk NATO systemy te potrafią wykrywać oznaki początku epidemii wystarczająco wcześnie, aby można było podejmować skuteczne środki zaradcze ${ }^{49}$. Systemy te charakteryzują się wysoką czułością, ale niską specyficznością generowanych alarmów. Niestety, po okresie rozwoju wiele $\mathrm{z}$ tych narzędzi zostało wycofanych, zapewne z powodu braku środków i personelu na podtrzymanie aktywnego pozyskiwania, analizy i weryfikacji częstych, fałszywie pozytywnych sygnałów ${ }^{50}$.

Nowe systemy wykorzystują dane zdrowotne z mediów społecznościowych i internetowych serwisów informacyjnych. Pozwala to na ominięcie, a jednocześnie na uzupełnienie tradycyjnych systemów biernego i aktywnego nadzoru epidemiologicznego, opartych na danych pochodzących z opieki zdrowotnej. Ten kierunek wywiadu epidemiologicznego przyjął miano cyfrowej detekcji chorób (digital disease detection). Monitorowanie serwisów internetowych pod kątem treści związanych z chorobami zakaźnymi jest osią działania kluczowych hubów informacyjnych jak kanadyjski GPHIN (Global Public Health Intelligence Network) czy sieć GOARN (Global Outbreak Alert and Response Network) Światowej Organizacji Zdrowia. Komponent wywiadu epidemiologicznego oparty na analizie zdarzeń korzysta z danych nieustrukturyzowanych, formalnych i nieformalnych, także odnośnie do zjawisk sprzyjających rozwojowi epidemii (drivers $)^{51}$. Informacja pochodzi bezpośrednio od świadków zdarzeń. Analizy „,ruchu” internetowego związanego ze słowami kluczowymi w serwisach typu Facebook, Twitter czy Wikipedia korelują z ogłaszanymi z opóźnieniem raportami lokalnych instytucji zdrowia publicznego, także w przypadku chorób przenoszonych przez wektory zwie-

${ }^{49}$ J.B. Meynard i in., Evaluation of the NATO Disease Surveillance System by its users in Kosovo in 2008, „Military Medicine” 2010, t. 175, nr 7, s. 466-468, https://doi.org/10.7205/ milmed-d-09-00122.

50 A.G. Huff $\mathrm{i}$ in., Biosurveillance: a systematic review of global infectious disease surveillance systems from 1900 to 2016, „Revue Scientifique et Technique de l'OIE” 2017, t. 36, nr 2, s. 513-524, https://doi.org/10.20506/rst.36.2.2670.

${ }^{51}$ S.H. Olson i in., Drivers of Emerging Infectious Disease Events as a Framework for Digital Detection, „Emerging Infectious Diseases” 2015, t. 21, nr 8, s. 1285-1292, https://doi. org/10.3201/eid2108.141156. 
rzęce (denga, malaria, leiszmanioza), choć trafność prognoz schodzi szczegółowo na poziom lokalny tylko w przypadkach niektórych komunikatorów (Twitter) ${ }^{52}$.

Należy jednak przyznać, że digitalizacja opieki zdrowotnej i zdrowia publicznego, obok podniesienia sprawności systemów, niesie ze sobą zagrożenia dla bezpieczeństwa opieki zdrowotnej. Sektor ten jest jednym z najbardziej podatnych i najatrakcyjniejszych dla cyberprzestępców, działających z pobudek finansowych, osobistych, ale także politycznych. Bezpieczeństwo cybernetyczne w tym sektorze zagrożone jest „hakowaniem” przez kryminalistów i terrorystów z zewnątrz systemów elektronicznej informacji medycznej, wprowadzaniem złośliwego oprogramowania celem wyłudzeń finansowych lub, co najczęstsze i najbardziej groźne, nieuwagą, nieświadomością lub celowym umożliwianiem dostępu do systemów przez uprawniony personel podmiotów leczniczych ${ }^{53}$. Do takich ataków, paraliżujących systemy szpitali, doszło w Wielkiej Brytanii i USA. Jak wykazały symulacje, wobec powszechnego trendu sieciowania urządzeń medycznych możliwe jest na masową skalę zakłócanie pracy sprzętu używanego przez indywidualnych pacjentów, np. wspomagającego oddech i monitorującego parametry życiowe w oddziałach intensywnej terapii, również rozruszników serca, pomp lekowych czy pracy laboratoriów ${ }^{54}$.

\section{Podsumowanie}

Chociaż w badaniach nad bezpieczeństwem zauważono, że kwestie niemilitarne, jak choroby zakaźne, degradacja środowiska i katastrofy humanitarne, stwarzają istotne zagrożenie dla światowego ładu, to wciąż część naukowców uważa, że badania te powinny dotyczyć konfliktów zbrojnych oraz zagrożeń wynikających z użycia siły wojskowej. Jednak po przyjętej w 2000 r. przez Radę Bezpieczeństwa rezolucji nr 1308, która ostrzegała, że nieopanowana pandemia HIV/ AIDS może stanowić zagrożenie dla stabilności i bezpieczeństwa, zagrożenie zdrowotne stało się problemem polityki globalnej, urosło do rangi zagrożenia bezpieczeństwa międzynarodowego. Obecnie tematyką tą zajmuje się nie tylko Organizacja Narodów Zjednoczonych ze Światową Organizacją Zdrowia, ale również Unia Europejska oraz wiele innych podmiotów, w tym organizacje pozarządowe. Niezależnie od wynikającej z mnogości zainteresowanych podmio-

52 S. Pollett, Internet-based biosurveillance methods for vector-borne diseases: Are they novel public health tools or just novelties?, „PLOS Neglected Tropical Diseases” 2017, nr 11(11), s. 58-71, https://doi.org/10.1371/journal.pntd.0005871.

53 L. Coventry, D. Branley, Cybersecurity in healthcare: A narrative review of trends, threats and ways forward, „Maturitas” 2018, t. 113, s. 48-52, https://doi.org/10.1016/j.maturitas.2018.04.008.

54 C.S. Kruse, B. Frederick, T. Jacobson, D.K. Monticone, Cybersecurity in healthcare: A systematic review of modern threats and trends, „Technology and Health Care” 2017, t. 25, nr 1, s. 1-10, https://doi.org/10.3233/thc-161263. 
tów rozbieżności w przyjętej definicji bezpieczeństwa zdrowotnego - związek pomiędzy zdrowiem a bezpieczeństwem istnieje, został zauważony i warto go nadal badać i analizować.

Zagrożenia bezpieczeństwa zdrowotnego można podzielić ze względu na ich źródło - na zewnętrzne i wewnętrzne. Decydenci z państw uprzemysłowionych kładą nacisk na ochronę ludności przed zewnętrznymi zagrożeniami bezpieczeństwa zdrowotnego, zwłaszcza przed terroryzmem i pandemiami.

W procesie przeglądu kolejnych "Strategii bezpieczeństwa narodowego RP” w obszarze bezpieczeństwa zdrowia publicznego należy uwzględnić rozwój narzędzi nadzoru i wywiadu epidemiologicznego przy wykorzystaniu najnowszych technologii analizy masowych danych cyfrowych dostępnych w internecie. Szczegółowe analizy ilościowe zjawisk przyczyniających się do rozwoju epidemii pozwalają na właściwą alokację środków na profilaktykę i reagowanie kryzysowe. Jednocześnie w dobie pożądanej digitalizacji zasobów danych opieki zdrowotnej i sieciowania urządzeń medycznych bardzo istotny jest rozwój cyberbezpieczeństwa w sektorze ochrony zdrowia.

\section{Bibliografia}

Aldis W., Health security as a public health concept: a critical analysis, „Health Policy and Planning" 2008, t. 23, nr 6, https://doi.org/10.1093/heapol/czn030.

Coventry L., Branley D., Cybersecurity in healthcare: A narrative review of trends, threats and ways forward, „Maturitas” 2018, t. 113, https://doi.org/10.1016/j.maturitas.2018.04.008.

Elbe S., Security and global health, Polity Press, Cambridge 2010.

Hackett D.W., Measles Epidemic in Ukraine Exceeds 28,000 Cases, 19 sierpnia 2018 r., https://www.precisionvaccinations.com/level-1-international-travel-alert-issued-cdc-measles-epidemic-ukraine.

Herriman R., Ukraine measles cases continue to climb, 2nd diphteria case reported, 21 czerwca 2018 r., http://outbreaknewstoday.com/ukraine-measles-cases-continue-climb-2nd-diphtheria-case-reported-90867/.

Heyman D., Lessons from the Anthrax Attacks: Implications for U.S. Bioterrorism Preparedness. A Report on a National Forum on Biodefense, kwiecień 2002 r., https:// biotech.law.lsu.edu/blaw/anthrax/dtra02.pdf.

Heymann D.L., West A., Emerging infections. Threats to health and economic security [w:] Routledge Handbook of Global Health Security, red. S. Rushton, J. Youde, Routledge, New York 2018.

Huff A.G. i in., Biosurveillance: a systematic review of global infectious disease surveillance systems from 1900 to 2016, „Revue Scientifique et Technique de l'OIE” 2017, t. 36, nr 2, https://doi.org/10.20506/rst.36.2.2670.

Kicman-Gawłowska A., Nadzór nad chorobami zakaźnymi w świetle Międzynarodowych Przepisów Zdrowotnych (2005), „Przegląd Epidemiologiczny” 2008, t. 62. 
Kocik J., Jędras M., Nowe wyzwania związane z migracją ludności, Bel Studio, Warszawa 2017. Kruse C.S., Frederick B., Jacobson T., Monticone D.K., Cybersecurity in healthcare: A systematic review of modern threats and trends, „Technology and Health Care” 2017, t. 25, nr 1, https://doi.org/10.3233/thc-161263.

Lonnroth K. i in., Tuberculosis in migrant in low-incidence countries: epidemiology and intervention entry points, „The International Journal of Tuberculosis and Lung Disease” 2017, t. 21, nr 6, https://doi.org/10.5588/ijtld.16.0845.

Martin G., Boland M., Planning and preparing for public health threats at airports, „Globalization and Health" 2018, t. 14, nr 28, https://doi.org/10.1186/s12992-0180323-3.

Meynard J.B. i in., Evaluation of the NATO Disease Surveillance System by its users in Kosovo in 2008, „Military Medicine” 2010, t. 175, nr 7, https://doi.org/10.7205/ milmed-d-09-00122.

McInnes C., The many meanings of health security [w:] Routledge Handbook of Global Health Security, red. S. Rushton, J. Youde, Routledge, New York 2015.

Olson S.H. i in., Drivers of Emerging Infectious Disease Events as a Framework for Digital Detection, „Emerging Infectious Diseases” 2015, t. 21, nr 8, https://doi.org/10.3201/ eid2108.141156.

Pollett S., Internet-based biosurveillance methods for vector-borne diseases: Are they novel public health tools or just novelties?, „PLOS Neglected Tropical Diseases” 2017, nr 11(11), https://doi.org/10.1371/journal.pntd.0005871.

Semenza J.C. i in., Observed and projected drivers of emerging infectious diseases in Europe, „Annals of the New York Academy of Sciences” 2016, t. 1382, nr 1, https://doi. org/10.1111/nyas.13132.

Semenza J.C., Zeller H., Integrated surveillance for prevention and control of emerging vector-borne diseases in Europe, „Eurosurveillance” 2014, t. 19, nr 13, https://doi. org/10.2807/1560-7917.ES2014.19.13.20757.

Solarz M.W., Choroby a wspótczesna mapa polityczna świata [w:] Ochrona zdrowia w stosunkach międzynarodowych, red. W. Lizak, A.M. Solarz, Wydawnictwa Uniwersytetu Warszawskiego, Warszawa 2015.

Tukidydes, Wojna peloponeska, Czytelnik, Warszawa 2003.

Wojtczak A., Zdrowie publiczne wyzwaniem dla systemów zdrowia XXI wieku, Wydawnictwo Lekarskie PZWL, Warszawa 2009.

\section{Akty prawne}

Decyzja Parlamentu Europejskiego i Rady nr 1082/2013/UE z 22 października 2013 r. w sprawie poważnych transgranicznych zagrożeń zdrowia oraz uchylająca decyzję nr 2119/98/WE, Dz.Urz.UE L293 z 5 listopada 2013 r.

Konstytucja Światowej Organizacji Zdrowia, http://prawo.sejm.gov.pl/isap.nsf/download.xsp/WDU19480610477/O/D19480477pdf.

Rada Bezpieczeństwa ONZ, Rezolucja nr 1308 w sprawie pandemii HIV/AIDS oraz międzynarodowych operacji pokojowych, 17 lipca 2000 r., http://www.unaids.org/ sites/default/files/sub_landing/files/20000717_un_scresolution_1308_en.pdf. 
Strategia bezpieczeństwa narodowego Rzeczypospolitej Polskiej, 2014, https://www.bbn. gov.pl/ftp/SBN\%20RP.pdf.

Ustawa z 26 kwietnia 2007 r. o zarządzaniu kryzysowym, Dz.U. nr 89 poz. 590.

Ustawa z 5 grudnia 2008 r. o zapobieganiu oraz zwalczaniu zakażeń i chorób zakaźnych u ludzi, Dz.U. nr 234 poz. 1570.

\section{Źródła internetowe}

Center for Disease Control and Prevention, Ebola, https://www.cdc.gov/niosh/topics/ ebola/.

Central Intelligence Agency, National Intelligence Estimate NIE99-17D: The Global Infectious Disease Threat and Its Implications for the United States, 2000, https://www. dni.gov/files/documents/infectiousdiseases_2000.pdf.

Centre for Research on the Epidemiology of Disasters, Annual Disaster Statistical Review 2016, http://emdat.be/sites/default/files/adsr_2016.pdf.

Centre for Research on the Epidemiology of Disasters, International Disaster Database, www.emdat.be.

Commission on Human Security, Human Security Now, New York 2003, https://reliefweb.int/sites/reliefweb.int/files/resources/91BAEEDBA50C6907C1256D1900 6A9353-chs-security-may03.pdf.

Europejskie Centrum ds. Zapobiegania i Kontroli Chorób, Technical report: Public health emergency preparedness, 2017, https://ecdc.europa.eu/sites/portal/files/documents/ public-health-emergency-preparedness-core-competencies-eu-member-states.pdf.

Europejskie Centrum ds. Zapobiegania i Kontroli Chorób, Technical report: Towards One Health preparedness, 2018, https:/ecdc.europa.eu/sites/portal/files/documents/ One-Health-preparedness-24-May-2018.pdf.

Europejski Trybunał Obrachunkowy, Special Report: Dealing with serious cross-border threats to health in the EU: important steps taken but more needs to be done, Luksemburg, Urząd Publikacji Unii Europejskiej, 2016, https://www.eca.europa.eu/Lists/ ECADocuments/SR16_28/SR_HEALTH_EN.pdf.

Federal Bureau of Investigation, Amerithrax or Anthrax Investigation, https://www.fbi. gov/history/famous-cases/amerithrax-or-anthrax-investigation.

Global Health Security Initiative, Ministerial Statement, 2002, http://www.ghsi.ca/english/statementlondonmar2002.asp.

Główny Inspektorat Sanitarny, Współpraca międzynarodowa, https://gis.gov.pl/en/zdrowie/transgraniczne-zagrozenia-zdrowia-publicznego/wspolpraca-miedzynarodowa.

Komisja Europejska, Health Security Committee members, https://ec.europa.eu/health/ preparedness_response/risk_management/hsc/membes_en.

Komisja Europejska, The new EU Framework on Health Security, 2016, https://epidemio. wiv-isp.be/ID/Documents/Seminar/SSID_2016/The_new_EU_Framework_on_Health_Security.pdf.

Ministerstwo Zdrowia, Jakość w opiece medycznej, http://www.mz.gov.pl/system-ochrony-zdrowia/organizacja-ochrony-zdrowia/jakosc-w-opiece-zdrowotnej/. 
ONZ, Millennium Development Goals, http://www.un.org/millenniumgoals/.

Program Narodów Zjednoczonych ds. Rozwoju, Human Development Report, 1994, http://hdr.undp.org/sites/default/files/gomez_hdr14.pdf.

Rządowe Centrum Bezpieczeństwa, Krajowy plan zarządzania kryzysowego, https://rcb. gov.pl/krajowy-plan-zarzadzania-kryzysowego/.

Szczepienia.Info, Coraz więcej zachorowań na odrę i drugi przypadek błonicy na Ukrainie, 27 czerwca 2018 r., http://szczepienia.pzh.gov.pl/coraz-wiecej-zachorowan-na-odre-i-drugi-przypadek-blonicy-na-ukrainie/.

Światowa Organizacja Turystyki, http://www2.unwto.org/press-release/2018-08-27/ unwto-highlights-confirm-another-record-year-2017.

WHO, Global health security: epidemic alert and response, WHO, Geneva 2001, http:// apps.who.int/iris/bitstream/10665/78789/1/ea54r14.pdf.

WHO, Antimicrobial resistance: global report on surveillance 2014, http://www.who.int/ iris/bitstream/10665/112642/1/9789241564748_eng.pdf?ua=1.

WHO, A Safer Future: Global Public Health Security in the 21st Century, The World Health Report 2007, Geneva, http://www.who.int/entity/whr/2007/whr07_en.pdf?ua=1.

WHO, Health Systems Strengthening Glossary, http://www.who.int/healthsystems/hss_ glossary/en/index8.html.

WHO, International travel and health, http://www.who.int/ith/ITH_EN_2012_ WEB_1.2.pdf?ua $=1$.

WHO, WHO situation report: Ukraine. April-June 2018, http://www.euro.who.int/ data/assets/pdf_file/0006/377484/who-sitrep-april-june-2018-eng.pdf?ua=1.

Timeline of Syrian Chemical Weapon Activity 2012-2018, https://www.armscontrol.org/ factsheets/Timeline-of-Syrian-Chemical-Weapons-Activity. 